\section{Needlestick-Associated Rocky Mountain Spotted Fever, Brazil}

\author{
Stefan Vilges de Oliveira, Álvaro A. Faccini-Martínez, \\ Talita Emile Ribeiro Adelino, Ana Íris de Lima Duré, \\ Amalia R.M. Barbieri, Marcelo B. Labruna
}

Author affiliations: Universidade Federal de Uberlândia, Uberlândia, Brazil (S.V. de Oliveira); Universidade Federal do Espírito Santo, Vitória, Brazil (Á.A. Faccini-Martínez); Fundação Ezequiel Dias, Belo Horizonte, Brazil (T.E. Ribeiro Adelino, A.Í. de Lima Duré); University of São Paulo, São Paulo, Brazil (A.R.M. Barbieri, M.B. Labruna)

\section{DOI: https://doi.org/10.3201/eid2604.191251}

We report a fatal case of Rocky Mountain spotted fever (RMSF) in a man in Brazil without recent history of tick bites or environmental exposure. He received an accidental needlestick while working as a nurse. The nurse and his patient died. Both cases were confirmed as RMSF by molecular methods.

A fter viruses, bacteria are the most common infection risk in healthcare workers who have accidental exposure to blood or body fluids (1). Accidental exposures mainly occur from percutaneous injury or mucocutaneous contact (1).

Rickettsia rickettsii is the etiological agent of Rocky Mountain spotted fever (RMSF), a severe tickborne disease endemic to the Americas (2). In Brazil, RMSF is a notifiable disease, and 411 deaths were registered during 2007-2015 (3). Men from rural areas who were exposed to ticks in the environment around forests, rivers, and waterfalls accounted for $>66 \%$ of cases (3). We report a fatal case of RMSF in a nurse who had no recent history of tick bite or environmental exposures.

In August 2018, two deaths in Minas Gerais state were classified as probable RMSF on the basis of clinical findings, including severe acute febrile syndrome. We retrospectively reviewed official report forms for the 2 cases (4). Case-patient A was a 74-year-old male farm worker from a rural area of Belo Horizonte municipality. On July 20, he began having symptoms of acute nonrash febrile syndrome, including myalgia, dysuria, and oliguria. He reported environmental exposure and an insect bite on his chest prior to onset of symptoms. He died on July 24 (Table).

Case-patient B was a 30-year-old man who had no history of recent travel, tick bites, or environmental exposures, nor did he own a dog. He was a nurse from the hospital where case-patient A was admitted. He reported an accidental percutaneous needlestick injury to his left thumb on July 23, after working with case-patient $\mathrm{A}$ in the hospital (Table). Following guidelines for biological hazards of healthcare workers in Brazil (5), clinicians collected blood from case-patient A and conducted serological tests for hepatitis B and C and HIV, all of which were negative. On July 30, casepatient $\mathrm{B}$ began having symptoms of acute febrile syndrome, including maculopapular rash, acute respiratory distress syndrome, shock, oliguria, thrombocytopenia, and leukopenia. Case-patient B died on August 5. Because RMSF was not suspected, neither case-patient received appropriate antimicrobial drugs.

After reviewing the official spotted fever case reports, we suspected $R$. rickettsii infection in both cases. We tested serum samples collected on July 22 from case-patient A and on August 2 from case-patient B. We used a Rickettsia genus-specific quantitative PCR to amplify rickettsial gltA gene from the patients' serum samples (6). Case-patient A had a cycle threshold value of 25.9 and case-patient B 35.3. We confirmed RMSF by using conventional heminested PCR protocol to amplify a 532-bp fragment of the rickettsial

Table. Information about confirmed fatal case of needlestick-associated Rocky Mountain spotted fever and related source case in Minas Gerais state, Brazil, 2018*

\begin{tabular}{|c|c|c|c|c|c|c|c|c|}
\hline \multirow[b]{2}{*}{$\begin{array}{l}\text { Case- } \\
\text { patient }\end{array}$} & \multirow[b]{2}{*}{$\begin{array}{l}\text { Age, } \\
\text { y/sex }\end{array}$} & \multirow[b]{2}{*}{$\begin{array}{l}\text { Clinical signs and } \\
\text { symptoms }\end{array}$} & \multirow[b]{2}{*}{ Exposure factors } & \multicolumn{3}{|c|}{ Date } & \multirow[b]{2}{*}{$\begin{array}{l}\text { qPCR } \\
(\text { gltA })\end{array}$} & \multirow{2}{*}{$\begin{array}{l}\text { Conventional } \\
\text { heminested } \\
\text { PCR }(o m p A) \dagger\end{array}$} \\
\hline & & & & $\begin{array}{c}\text { Symptom } \\
\text { onset }\end{array}$ & $\begin{array}{c}\text { Serum } \\
\text { collected }\end{array}$ & Death & & \\
\hline A, patient & $74 / \mathrm{M}$ & $\begin{array}{l}\text { Fever, myalgia, } \\
\text { dysuria, oliguria }\end{array}$ & $\begin{array}{l}\text { Environmental exposure to } \\
\text { woods, rivers, waterfalls; } \\
\text { report of insect bite }\end{array}$ & Jul 20 & Jul 22 & Jul 24 & + & + \\
\hline$B$, nurse & $30 / \mathrm{M}$ & $\begin{array}{c}\text { Fever, } \\
\text { maculopapular rash, } \\
\text { acute respiratory } \\
\text { distress syndrome, } \\
\text { shock, oliguria }\end{array}$ & $\begin{array}{l}\text { No reported tick or insect } \\
\text { bites or environmental } \\
\text { exposures; accidental } \\
\text { percutaneous needlestick } \\
\text { injury associated with case- } \\
\text { patient A on July } 23\end{array}$ & Jul 30 & Aug 2 & Aug 5 & + & + \\
\hline
\end{tabular}

${ }^{*}$ Clinical and epidemiological data were retrieved from official spotted fever-rickettsiosis case forms collected for each patient by the Ministry of Health, Brazil (4). gltA, rickettsial citrate synthase gene; ompA, rickettsial outer membrane protein A gene; qPCR, quantitative PCR; +, positive.

†All PCR amplicons were sequenced and confirmed a $100 \%$ identity with Rickettsia rickettsii. 
ompA gene, as previously described (6). Rickettsial DNA from the samples generated sequences with $100 \%$ identity to the corresponding ompA gene fragment of $R$. rickettsii (GenBank accession no. CP003305).

Besides the common transmission route through arthropod bite for infection, rare instances of $R$. rickettsii infection have been reported through accidental exposure in research laboratories or by percutaneous needlestick injuries in healthcare facilities. For instance, Johnson et al. described a series of 5 cases of laboratory-acquired RMSF cases in 1967, two of which occurred in workers who had accidental needlesticks involving a yolk-sac suspension of $R$. rickettsii (7). Both developed an acute febrile illness but were successfully treated with tetracycline (7). In another published case in a healthcare worker, a physician incurred a needlestick wound on his arm while assisting in the care of a patient with a presumptive diagnosis of RMSF. The patient died (8). The physician experienced sudden onset of a febrile illness 7 days after the puncture wound and a subsequent maculopapular rash. RMSF was confirmed by serological tests, and he was treated with oral tetracycline and recovered.

In accidental exposure, the risk of transmission varies according to the volume of blood inoculated and the number of infective agents in the inoculum (1). Median infective doses of rickettsiae are known to increase after endothelium destruction in severe cases of RMSF (9). In this case, when punctured with a needle, case-patient B probably was exposed to a high number of rickettsia released in the bloodstream of case-patient A just 1 day before his death.

Our report highlights the importance of considering RMSF in patients with symptoms compatible with the disease and in healthcare workers caring for patients with undifferentiated fever in RMSF-endemic areas. Administering doxycycline before a rash occurs and within 5 days of symptom onset is crucial to patient recovery. Patients with a history of an arthropod bite, sudden onset of fever, and exposure in an endemic area should prompt clinicians to provide immediate treatment. Primary, secondary, and tertiary healthcare facilities should educate and remind staff about RMSF and its associated signs and symptoms in patients.

Á.A.F.-M. was funded in part by the Coordenação de Aperfeiçoamento de Pessoal de Nível Superior, Brazil (CAPES; Finance Code 001).

\section{About the Author}

Dr. Oliveira is a professor in the School of Medicine, Federal University of Uberlândia, Uberlândia, Brazil. His primary research interests include epidemiology of zoonotic and vectorborne diseases.

\section{References}

1. Tarantola A, Abiteboul D, Rachline A. Infection risks following accidental exposure to blood or body fluids in health care workers: a review of pathogens transmitted in published cases. Am J Infect Control. 2006;34:367-75. https://doi.org/10.1016/j.ajic.2004.11.011

2. Hidalgo M, Faccini-Martínez ÁA, Valbuena G. Tick-borne rickettsioses in the Americas: clinical and epidemiological advances, and diagnostic challenges [in Spanish]. Biomedica. 2013;33(Suppl 1):161-78.

3. de Oliveira SV, Guimarães JN, Reckziegel GC, Neves BM, Araújo-Vilges KM, Fonseca LX, et al. An update on the epidemiological situation of spotted fever in Brazil. J Venom Anim Toxins Incl Trop Dis. 2016;22:22. https:/ / doi.org/10.1186/s40409-016-0077-4

4. Ministry of Health, Brazil. Official spotted fever/rickettsiosis case report [in Portuguese]. Brazil: The Ministry; 2018 [cited 2020 Feb 17]. http:/ / portalsinan.saude.gov.br/ images/documentos/Agravos/Febre\%20Maculosa/ Febre_Maculosa_v5.pdf

5. Ministry of Health, Brazil. Exposure to biological materials [in Portuguese]. Brazil: The Ministry; 2006 [cited 2020 Feb 17]. http:/ / bvsms.saude.gov.br/bvs/publicacoes/ protocolo_expos_mat_biologicos.pdf

6. Faccini-Martínez ÁA, Muñoz-Leal S, Acosta ICL, de Oliveira SV, de Lima Duré AÍ, Cerutti C, et al. Confirming Rickettsia rickettsii as the etiological agent of lethal spotted fever group rickettsiosis in human patients from Espírito Santo state, Brazil. Ticks Tick Borne Dis. 2018;9:496-9. https://doi.org/10.1016/ j.ttbdis.2018.01.005

7. Johnson JE III, Kadull PJ. Rocky Mountain spotted fever acquired in a laboratory. N Engl J Med. 1967;277:842-7. https:/ / doi.org/10.1056/NEJM196710192771603

8. Sexton DJ, Gallis HA, McRae JR, Cate TR. Letter: possible needle-associated Rocky Mountain spotted fever. N Engl J Med. 1975;292:645. https:/ /doi.org/10.1056/ NEJM197503202921217

9. Kaplowitz LG, Lange JV, Fischer JJ, Walker DH. Correlation of rickettsial titers, circulating endotoxin, and clinical features in Rocky Mountain spotted fever. Arch Intern Med. 1983;143:1149-51. https:/ / doi.org/10.1001/ archinte.1983.00350060073012

\footnotetext{
Address for correspondence: Álvaro A. Faccini-Martínez, Postgraduate Program in Infectious Diseases, Health Science Center, Universidade Federal do Espírito Santo, Av Marechal Campos, 1468-Maruípe, Vitória, ES, Brazil; email: afaccini@gmail.com
} 